STRUCTURAL BIOLOGY COMMUNICATIONS

ISSN 2053-230X

Received 3 March 2017

Accepted 24 May 2017

Edited by I. Tanaka, Hokkaido University, Japan

Keywords: Clostridium difficile; MarR; crystal structure; transcription factors; DNA binding; antibiotic resistance.

PDB reference: MarR, 5eri

Supporting information: this article has supporting information at journals.iucr.org/f

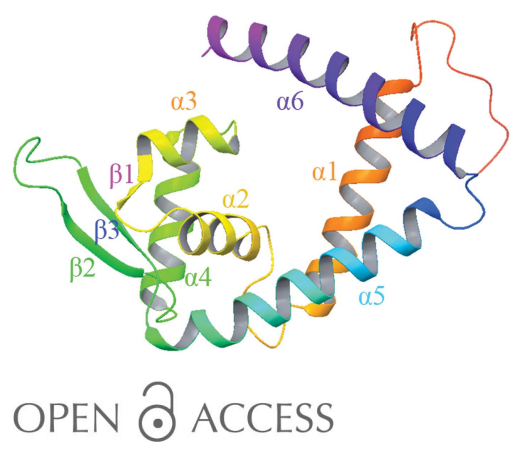

\section{Crystal structure of the multiple antibiotic resistance regulator MarR from Clostridium difficile}

\author{
J. W. Peng, H. Yuan and X. S. Tan*
}

Department of Chemistry, Fudan University, 220 Handan Road, Shanghai 200433, People's Republic of China. *Correspondence e-mail: xstan@fudan.edu.cn

Regulators of multiple antibiotic resistance (MarRs) are key players against toxins in prokaryotes. MarR homologues have been identified in many bacterial and archaeal species which pose daunting antibiotic resistance issues that threaten public health. The continuous prevalence of Clostridium difficile infection (CDI) throughout the world is associated with the abuse of antibiotics, and antibiotic treatments of CDI have limited effect. In the genome of C. difficile strain 630, the marR gene (ID 4913953) encodes a MarR protein. Here, MarR from C. difficile (MarR $\mathrm{R}_{\text {.difficile }}$ ) was subcloned and crystallized for the first time. MarR $\mathrm{R}_{\text {C.difficile }}$ was successfully expressed in Escherichia coli in a soluble form and was purified to near-homogeneity $(>95 \%)$ by a two-step purification protocol. The structure of $\mathrm{MarR}_{\text {C.difficile }}$ has been solved at $2.3 \AA$ resolution. The crystal belonged to the monoclinic space group $P 4_{3} 2_{1} 2$, with unit-cell parameters $a=b=66.569, c=83.654 \AA$. The structure reported reveals $\operatorname{MarR}_{\text {C.difficile }}$ to be a dimer, with each subunit consisting of six $\alpha$-helices and three antiparallel $\beta$-hairpins. MarR $\mathrm{R}_{\text {Cdifficile }}$ shows high structural similarity to the MarR proteins from E. coli and Staphylococcus aureus, indicating that MarR $_{\text {C.difficile }}$ might be a DNA-binding protein.

\section{Introduction}

Clostridium difficile is an anaerobic human pathogen that causes acute healthcare-associated diarrhoea. The morbidity and mortality rates of $C$. difficile infection (CDI) have increased dramatically in Europe and in North America (Heinlen \& Ballard, 2010); the emergence of $C$. difficile strains that are resistant to multiple antibiotic agents can complicate prevention programs and potential treatments (Hunt \& Ballard, 2013). Many studies have demonstrated that various bacterial species employ MarR homologues to sense and exert resistance against many cellular toxins from the environment or host immune system, including multiple antibiotics, oxidative reagents and disinfectants (Cohen et al., 1993; Alekshun \& Levy, 1999). The regulator of multiple antibiotic resistance (MarR) in Escherichia coli, a member of the MarR family of regulator proteins, modulates bacterial detoxification in response to diverse antibiotics (Hao et al., 2014). The transcription factors of the MarR family regulate diverse genes involved in multiple antibiotic resistance, the synthesis of virulence determinants and many other important biological processes (Martin et al., 1995; Alekshun \& Levy, 1997; Perera \& Grove, 2010). The MarR protein, as a member of the MarR family of multiple antibiotic resistance proteins, is a key global regulator in $C$. difficile. A link between MarR family proteins and antibiotic resistance has been suggested in previous studies (George \& Levy, 1983). However, the function of 
MarR in C. difficile is still unknown. Here, we aim to study the biological function of MarR from the perspective of its crystal structure. Thus, the major work in this article is to report the crystal structure of MarR from C. difficile (MarR $\mathrm{M}_{\text {.difficile }}$ ).

In this study, we solved the crystal structure of MarR $\mathrm{R}_{\text {.difficile }}$ by molecular replacement. Diffraction data were collected to $2.3 \AA$ resolution. The overall structure indicated that $\operatorname{MarR}_{\text {C.difficile }}$ is a homodimer, with each subunit consisting of six helical regions and three $\beta$-strands. Like other MarR proteins, the helical regions in each subunit contribute to the protein-protein interface in the dimer. An analysis of electrostatic surface potential shows a putative DNA-binding site, as observed in other MarR family proteins. This is the first reported crystal structure of this protein from $C$. difficile.

\section{Materials and methods}

\subsection{Protein preparation}

The gene encoding MarR (annotated in GenBank as CAJ67669.1) was PCR-amplified using $C$. difficile 630 genomic DNA as template, into which NdeI and EcoRI restriction sites were introduced. The purified PCR product was digested with the corresponding restriction enzymes and ligated with T4 DNA ligase into the pET-28a(+) vector (Novagen). The resulting construct contained a hexahistidine tag at the $\mathrm{N}$-terminus of MarR and a thrombin cleavage site. The constructed plasmid was transformed into E. coli BL21 cells for expression. The E. coli cells were grown in LB medium containing $100 \mu \mathrm{g} \mathrm{ml}^{-1}$ kanamycin at $37^{\circ} \mathrm{C}$ to an $\mathrm{OD}_{600}$ of 0.6 before IPTG was added to a final concentration of $0.4 \mathrm{mM}$. Protein expression was induced at $20^{\circ} \mathrm{C}$ for $12 \mathrm{~h}$ before harvesting. The cell pellets were collected and resuspended in NTA buffer $(20 \mathrm{~m} M$ Tris-HCl pH 7.6, $200 \mathrm{mM} \mathrm{NaCl}, 10 \%$ glycerol) containing $1 \mathrm{~m} M$ phenylmethanesulfonyl fluoride (PMSF). After sonication on ice for $30 \mathrm{~min}$, the cell lysate was

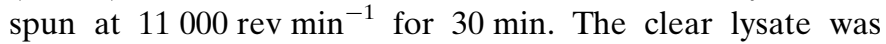
filtrated and loaded onto a HisTrap column ( $5 \mathrm{ml}$ column, GE Healthcare), which had been pre-equilibrated with $50 \mathrm{ml} \mathrm{NTA}$ buffer (Hao et al., 2014), for nickel-affinity chromatography. The $\mathrm{MarR}_{\text {C.difficile }}$ protein was then eluted with a linear imidazole gradient followed by a further purification step using a HiLoad 16/60 Superdex 200 column (GE Healthcare) equilibrated with buffer $A(20 \mathrm{~m} M$ Tris- $\mathrm{HCl}$ pH 7.6, $200 \mathrm{~m} M$ $\mathrm{NaCl}$ ). The eluted protein was purified to $>95 \%$ homogeneity as determined by $16 \%$ SDS-PAGE analysis (Fig. 1). The protein was collected and concentrated for crystallization screening.

Information relating to the production of recombinant MarR is summarized in Table 1.

\subsection{Crystallization}

Crystals of MarR $\mathrm{R}_{\text {C.difficile }}$ were grown at $16^{\circ} \mathrm{C}$ by hangingdrop vapour diffusion. $2 \mu \mathrm{l}$ purified protein $\left(5 \mathrm{mg} \mathrm{ml}^{-1}\right)$ in $200 \mathrm{~m} M \mathrm{NaCl}, 20 \mathrm{~m} M$ Tris $\mathrm{pH} 7.6$ was mixed with $2 \mu \mathrm{l}$ reservoir buffer $[10 \%(v / v)$ 2-propanol, $100 \mathrm{mM}$ Tris $\mathrm{pH}$ 7.6]. The droplets were equilibrated against $400 \mu \mathrm{l}$ reservoir buffer. Crystals were looped-out and soaked in cryoprotectant [crystallization buffer containing $20 \%(v / v)$ glycerol] before flash-cooling and storage in liquid nitrogen. Crystallization information is summarized in Table 2.

\subsection{Data collection and processing}

X-ray diffraction data were collected to $2.3 \AA$ resolution on beamline BL17U at the Shanghai Synchrotron Radiation Facility (SSRF). Crystals were flash-cooled in mother liquor at the beamline before data collection. All data were processed

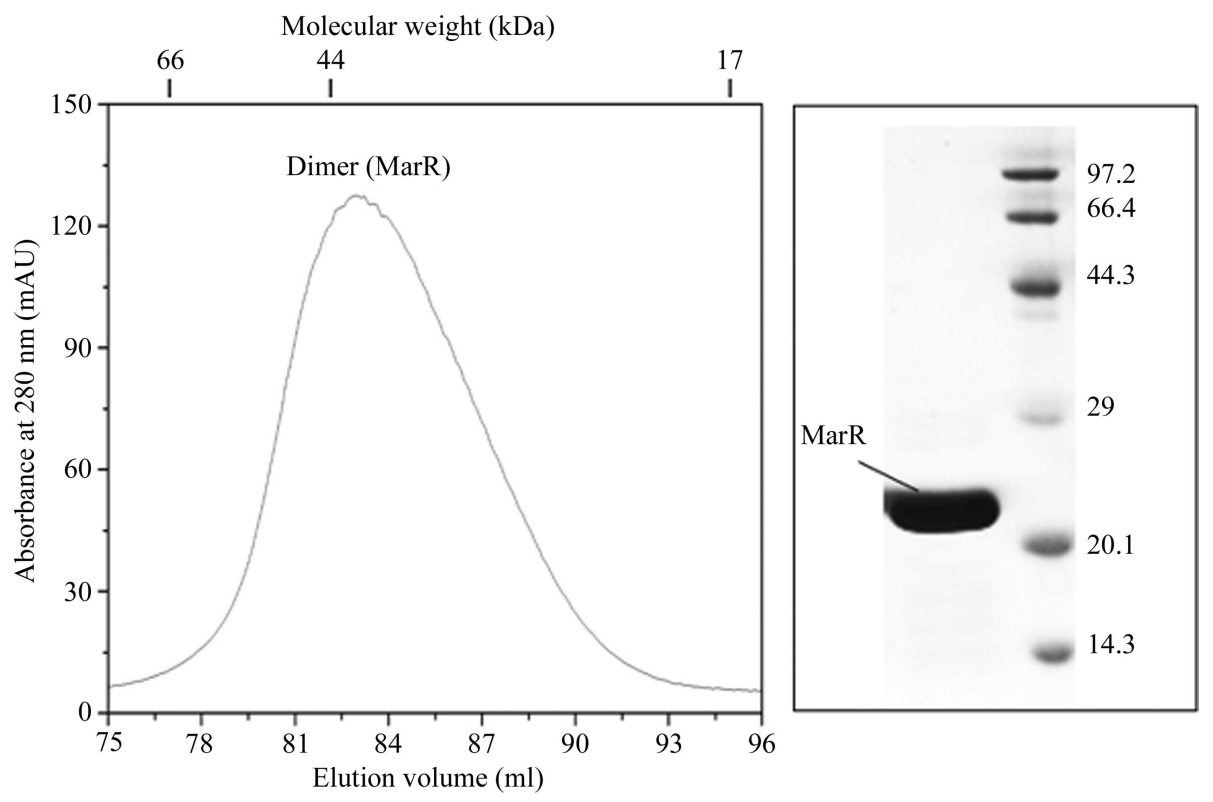

Figure 1

Elution profile of MarR $\mathrm{M}_{\text {.difficile }}$ from a Superdex 200 HiLoad 16/60 gel-filtration column on an ÄKTAexplorer FPLC system. The peak at $82 \mathrm{ml}$ (the flow

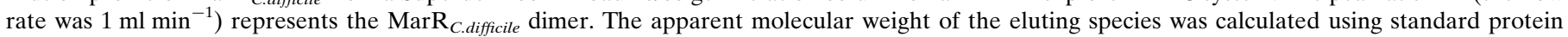
markers (Gel Filtration LMW Calibration Kit, GE Healthcare). The right panel shows SDS-PAGE analysis of the collected fraction. 
Table 1

Information relating to the production of recombinant MarR.

\begin{tabular}{ll}
\hline Source organism & C. difficile \\
DNA source & C. difficile strain 630 genomic DNA \\
Forward primer $\dagger$ & 5'-GCGCGCGGGAATTCCATATGTTGATTAAGAC- \\
& TTTAGATAGTAATATATTAAGAG-3' \\
Reverse primer $\ddagger$ & 5'-GCCCGGAATTCCTATCTCTTTACTTTAAACC- \\
& ATTCATTTTCTACG-3' \\
Cloning vector & pET-28a(+) (Novagen) \\
Expression vector & pET-28a(+) (Novagen) \\
Expression host & E. coli BL21 \\
Complete amino-acid sequence & MGSSHHHHHSSGLVPRGSHMLIKTLDSNILREV- \\
\cline { 2 - 2 } of the construct produced§ & GTLSRAVNSINDIKYKELKLQKGQFTFLTRIC- \\
& ENPGINLVELSNMKVDKATTTKAIQKLIKAG- \\
& YVDKKQDKFDKGYNLTPTDKSLEVYELIIEE- \\
& ENRSIEICFDNFTDEEKQVVTKLLEKMSKNVE- \\
& NEWFKVKR
\end{tabular}

$\dagger$ The NdeI site for cloning is underlined. $\ddagger$ The EcoRI site for cloning is underlined. $\S$ The N-terminal hexahistidine tag, linker and thrombin cleavage site are underlined.

Table 2

Crystallization.

\begin{tabular}{ll}
\hline Method & Vapour diffusion, hanging drop \\
Plate type & 24-well \\
Temperature (K) & 289 \\
Protein concentration $\left(\mathrm{mg} \mathrm{ml}^{-1}\right)$ & 5 \\
Buffer composition of protein & $20 \mathrm{~m} M$ Tris pH 7.6, 200 $\mathrm{mM} \mathrm{NaCl}$ \\
$\quad$ solution & \\
Composition of reservoir solution & $10 \%$ 2-propanol, $0.1 M$ Tris- $\mathrm{HCl} \mathrm{pH} 7.6$ \\
Volume and ratio of drop & $4 \mu \mathrm{l}, 1: 1$ \\
Volume of reservoir (ml) & 0.4
\end{tabular}

and reduced using $H K L-2000$ (Otwinowski \& Minor, 1997). The space group of the MarR crystals was determined to be $P 4_{3} 2{ }_{1} 2$, with one molecule in the asymmetric unit and with unit-cell parameters $a=b=66.57, c=83.65 \AA$ А,$\alpha=\beta=\gamma=90^{\circ}$ for the native protein. Data-collection and processing statistics are summarized in Table 3.

\subsection{Structure solution and refinement}

The structure was solved by molecular replacement using SlyA from Listeria monocytogenes (PDB entry 4mnu; Midwest Center for Structural Genomics, unpublished work) as the starting model. The structure was refined using

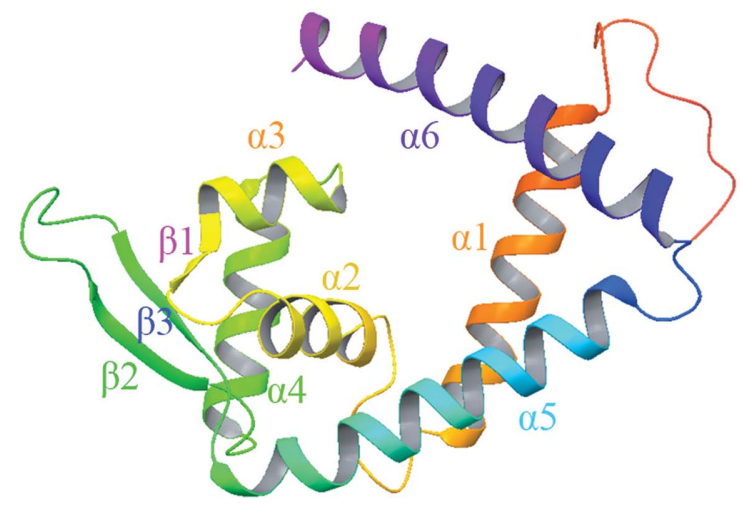

(a)
Table 3

Data collection and processing.

\begin{tabular}{ll}
\hline Diffraction source & Beamline BL17U, SSRF \\
Wavelength $(\AA)$ & 0.988 \\
Temperature $(\mathrm{K})$ & 100 \\
Detector & ADSC 315r \\
Crystal-to-detector distance $(\mathrm{mm})$ & 250 \\
Rotation range per image $\left({ }^{\circ}\right)$ & 1 \\
Total rotation range $\left({ }^{\circ}\right)$ & 180 \\
Exposure time per image (s) & 1 \\
Space group & $P 4_{3} 2_{1} 2$ \\
$a, b, c(\AA)$ & $66.57,66.57,83.65$ \\
$\alpha, \beta, \gamma\left({ }^{\circ}\right)$ & $90,90,90$ \\
Mosaicity $\left({ }^{\circ}\right)$ & 0.520 \\
Resolution range $(\AA)$ & $50-2.297(2.34-2.30)$ \\
Total No. of reflections & 207959 \\
No. of unique reflections & 8352 \\
Completeness $(\%)$ & $93.8(98.8)$ \\
Multiplicity & $24.9(28.5)$ \\
$\langle I / \sigma(I)\rangle$ & $77.0(16.01)$ \\
$R_{\text {merge }}$ & $0.080(0.530)$ \\
$R_{\text {r.i.m. }}$ & $0.087(0.604)$ \\
$R_{\text {p.i.m. }}$ Overall $B$ factor from Wilson plot $\left(\AA^{2}\right)$ & $0.019(0.110)$ \\
\hline
\end{tabular}

REFMAC 5.7.0032 (Winn et al., 2011; Potterton et al., 2003; Murshudov et al., 2011). Finally, the structure was deposited in the Protein Data Bank as PDB entry 5eri. The structuresolution and refinement statistics are summarized in Table 4 .

\section{Results and discussion}

\subsection{Overall structure of $M a r R_{C . d i f f i c i l e}$}

The crystal structure of MarR $\mathrm{R}_{\text {Cdifficile }}$ was determined by molecular replacement using SlyA (PDB entry 4mnu) as a search model. Like other MarR proteins, the MarR $\mathbf{R}_{\text {.difficile }}$ protein is composed of six $\alpha$-helices and a three-stranded antiparallel $\beta$-hairpin (Fig. 2a). The $\alpha 2, \alpha 3$ and $\alpha 4$ helices and two antiparallel $\beta$-strands, $\beta 2$ and $\beta 3$, are probably responsible for DNA binding, as indicated by the electrostatic surface potential (Figs. 2 and 3). The two putative DNA-binding domains in each subunit result in the formation of a channel through the centre of the dimer (Figs. 2 and 3). Consistent with previous studies, the putative DNA-binding regions of the

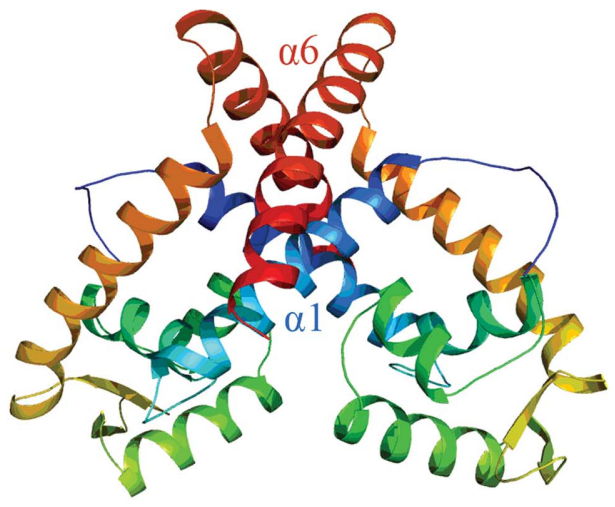

(b)

Figure 2

The structure of $\operatorname{MarR}_{\text {C.difficile. }}$ (a) One MarR $\mathrm{R}_{\text {.difficile }}$ subunit with labelled secondary structure. (b) Ribbon representation of the crystal structure of the MarR $\mathrm{R}_{\text {C.difficile }}$ dimer viewed with the subunit twofold axis close to vertical. 
Table 4

Structure solution and refinement.

\begin{tabular}{ll}
\hline Resolution range $(\AA)$ & $25.73-2.30(2.357-2.297)$ \\
Completeness $(\%)$ & $93.8(98.8)$ \\
$\sigma$ Cutoff & $I>3 \sigma(I)$ \\
No. of reflections, working set & $7915(586)$ \\
No. of reflections, test set & $394(26)$ \\
Final $R_{\text {cryst }}$ & $0.212(0.280)$ \\
Final $R_{\text {free }}$ & $0.250(0.318)$ \\
Cruickshank DPI & 0.337 \\
No. of non-H atoms & \\
$\quad$ Protein & 1246 \\
$\quad$ Ligand & 0 \\
$\quad$ Water & 33 \\
$\quad$ Total & 1279 \\
R.m.s. deviations & \\
$\quad$ Bonds $(\AA)$ & 0.019 \\
$\quad$ Angles $\left({ }^{\circ}\right)$ & 1.789 \\
Average $B$ factors $\left(\AA^{2}\right)$ & \\
$\quad$ Protein & 59.9 \\
$\quad$ Water & 56.2 \\
Ramachandran plot & \\
$\quad$ Most favoured $(\%)$ & 99 \\
$\quad$ Allowed $(\%)$ & 1 \\
\hline
\end{tabular}

$\operatorname{MarR}_{\text {C.difficile }}$ protein are strongly electropositive, as are other winged-helix DNA-binding proteins (Gajiwala \& Burley, 2000).

The structure of MarR from E. coli $\left(\operatorname{MarR}_{\text {E.coli }}\right)$ is a homodimer (Alekshun et al., 2001), and it has been verified that $\mathrm{MarR}_{\text {E.coli }}$ binds the $\operatorname{marR} A B$ promoter as a dimer (Martin et al., 1996). A recent study showed that disulfide bonds could be formed between MarR $_{\text {E.coli }}$ dimers, resulting in the dissociation of MarR $\mathrm{R}_{\text {.coli }}$ from its cognate DNA and enhanced bacterial resistance (Zhu et al., 2017). The MarR family member MprA also functions as a dimer (Brooun et al., 1999). PISA analysis suggested that $\mathrm{MarR}_{\text {C.difficile }}$ is a homodimer. In the crystal structure of $\mathrm{MarR}_{\text {C.difficile }}$ there is one monomer in the asymmetric unit, with the dimer being composed of two subunits related by a crystallographic twofold rotation. The crystal structure also indicates that $\alpha$-helices in the $\mathrm{N}$ - and $\mathrm{C}$-terminal regions of each subunit interdigitate with those of the other subunit to form a hydrophobic core burying a surface area of $3100 \AA^{2}$. Two helical regions, $\alpha 1$ and $\alpha 6$ (residues $9-27$ in the $\mathrm{N}$-terminus and residues 123-147 in the C-terminus, respectively), are closely juxtaposed and intertwine with the equivalent regions of the second subunit to form a dimer. The dimer is stabilized by several salt bridges, notably that between Arg16 and Glu74' and that between Lys155 and Glu145'. In addition, a hydrogen bond between the side-chain carbonyl $\mathrm{O}$ atom of Glu66 and the guanidinium NH groups of Arg31' enhances the stability of the dimeric structure.

\subsection{Comparison of $M a r R_{C . d i f f i c i l e}$ with $M a r R_{E . c o l i}$ and MgrA $_{\text {s.aureus }}$}

MgrA from Staphylococcus aureus $\left(\operatorname{MgrA}_{\text {S.aureus }}\right)$ is a regulator of antibiotic resistance and is also an important virulence determinant during infection (Ingavale et al., 2005). A previous study indicated that the cysteine residue (Cys12) of this protein could be oxidized by various reactive oxygen species. Cysteine oxidation leads to the dissociation of MgrA from DNA, resulting in the initiation of signalling pathways and further enhancing antibiotic resistance in $S$. aureus (Chen et al., 2006). The oxidation-sensing mechanism is widely used by bacteria to counter challenges of environmental pressure (Lee \& Helmann, 2006). In conclusion, MgrA from S. aureus is an oxidation sensor.

Previous studies reported that the MarR family of proteins are typically conserved transcription factors that modulate bacterial resistance to multiple antibiotics, oxidative reagents and detergents (Martin \& Rosner, 1995). Various bacterial species such as $E$. coli can respond to environmental stresses such as toxic chemicals and disinfectants by triggering the dissociation of MarR from the cognate DNA in a copperdependent manner. The detailed mechanism is that copper(II) oxidizes a unique cysteine residue (Cys80) that resides in the DNA-binding domain of MarR $\mathrm{R}_{\text {Ecoli }}$ to generate inter-dimer disulfide bonds, thereby inducing tetramer formation and the dissociation of MarR from the marRAB promoter (Hao et al., 2014). Therefore, MarR from E. coli is a copper signal oxidation sensor.

Sequence alignment of $\operatorname{MarR}_{\text {C.difficile }}$ with $\mathrm{MarR}_{\text {E.coli }}$ and $\operatorname{MgrA}_{\text {S.aureus }}$ using MUSCLE shows 26 and 19\% sequence identity; these proteins share low sequence similarity (Fig. 4). However, superposition of MarR $\mathrm{R}_{\text {.difficile }}$ with $\mathrm{MgrA}_{\text {S.aureus }}$ (PDB entry 2bv6; Chen et al., 2006) and MarR E.coli $_{\text {(PDB entry }}$ 1jgs; Alekshun et al., 2001) shows structural similarity (Fig. 5).

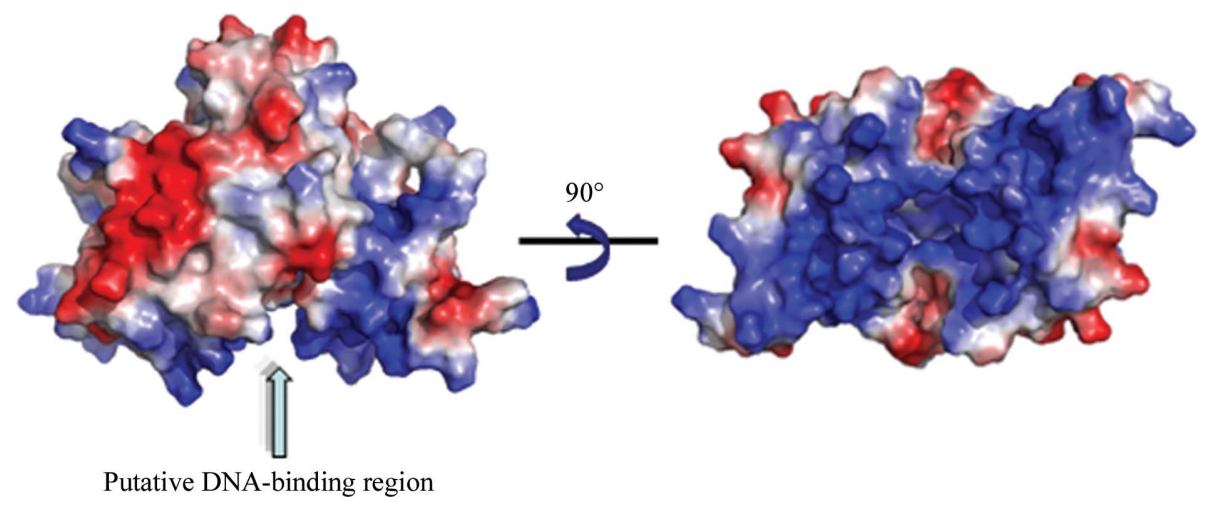

Figure 3

Electrostatic surface representation of the MarR $\mathrm{R}_{\text {cdifficile }}$ dimer. The putative DNA-binding sites are indicated by an arrow. 
The $\operatorname{MgrA}_{\text {S.aureus }}$ dimer is triangular in shape, with two wingedhelix DNA-binding domains; the DNA-binding domain includes two $\alpha$-helices, two $\beta$-sheets and a wing region (Chen et al., 2006). The structure of Mar $\mathrm{R}_{E \text {.coli }}$ is a crystallographic dimer, with each subunit containing a winged-helix DNAbinding motif, and this DNA-binding motif contains three $\alpha$-helices and two $\beta$-strands (Alekshun et al., 2001). We found that the crystal structure reveals $\mathrm{MarR}_{\text {C.difficile }}$ to be a dimer, with each monomer consisting of six $\alpha$-helices and a threestranded antiparallel $\beta$-hairpin. The putative DNA-binding domain of each subunit includes three $\alpha$-helices and two antiparallel $\beta$-strands. Correspondingly, MarR $\mathrm{R}_{\text {E.coli }}$ and $\operatorname{MgrA}_{\text {S.aureus }}$ share a similar oxidation-sensing mechanism in which cysteine oxidation leads to the dissociation of MarR $\mathbf{E}_{\text {.coli }}$ and $\operatorname{MgrA}_{\text {S.aureus }}$ from DNA. As a result, they exhibit a similar function. However, the function of MarR in $C$. difficile remains unknown. Structural analysis of $\mathrm{MarR}_{\text {C.difficile }}$ indicated that two cysteine residues (Cys45 and Cys117) are located in the hydrophobic core; this may suggest that MarR in $C$. difficile is probably not an oxidation sensor. Although they share structural similarity, these proteins might have diverse molecular mechanisms.

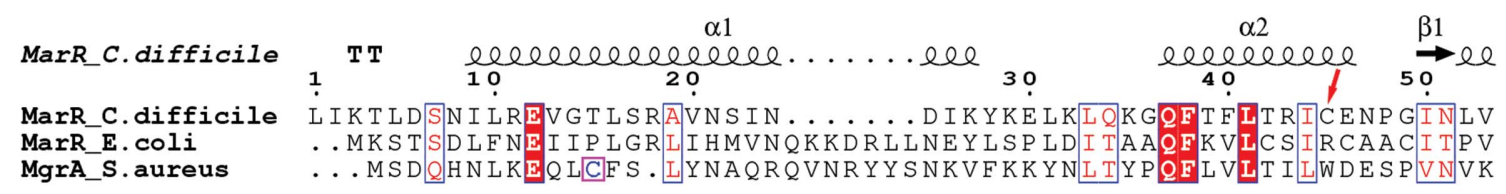

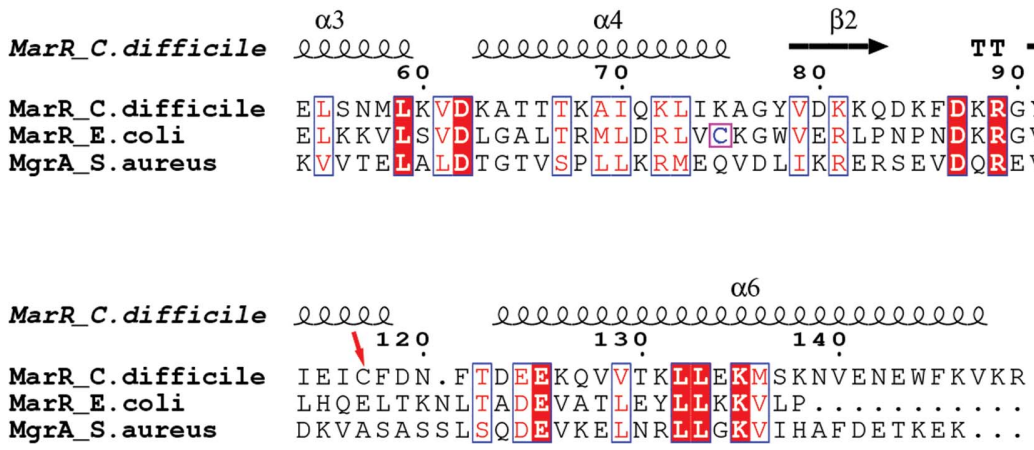

Figure 4

Primary-sequence alignment of MarR $\mathrm{R}_{\text {C.difficile }}$ with representative members of the MarR family $\left(\operatorname{MarR}_{\text {E.coli }}\right.$ and Mgr $\left.\mathrm{A}_{\text {S.aureus }}\right)$. The secondary-structural elements of MarR $\mathrm{R}_{\text {C.difficile }}$ are indicated above the sequence alignment: $\alpha$-helices $(\alpha)$ are illustrated as curly lines and arrows represent $\beta$-sheets $(\beta)$. Numbering is according to the $\mathrm{MarR}_{\text {C.difficile }}$ primary sequence. Residues that are identical in all homologues are highlighted in red and highly conserved amino acids are shown in blue boxes. Red arrows indicate the cysteine residues of $\mathrm{MarR}_{\text {C.difficile }}$; the key cysteine residues of MarR $\mathrm{E}_{\text {.coli }}$ and $\mathrm{MgrA}_{\text {S.aureus }}$ are shown in purple boxes.

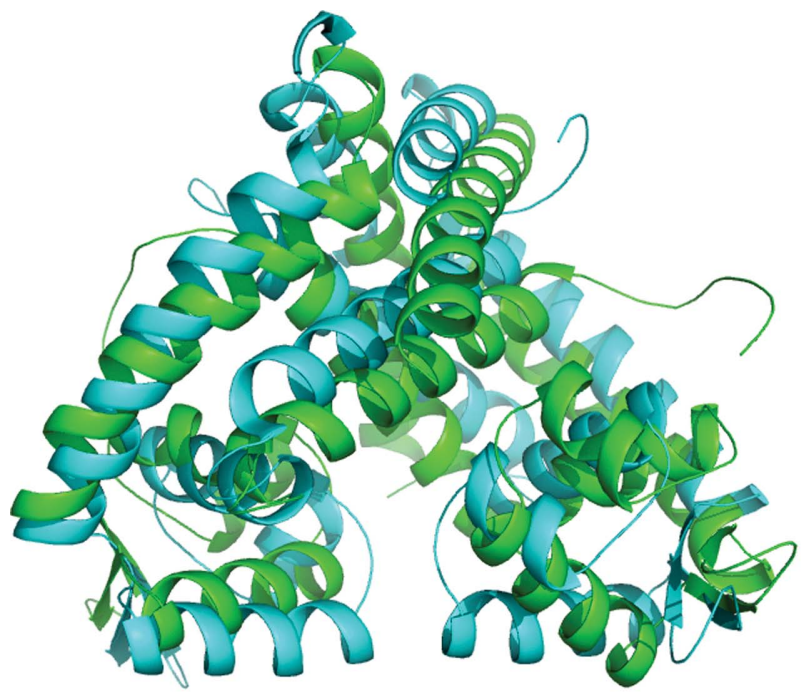

(a)

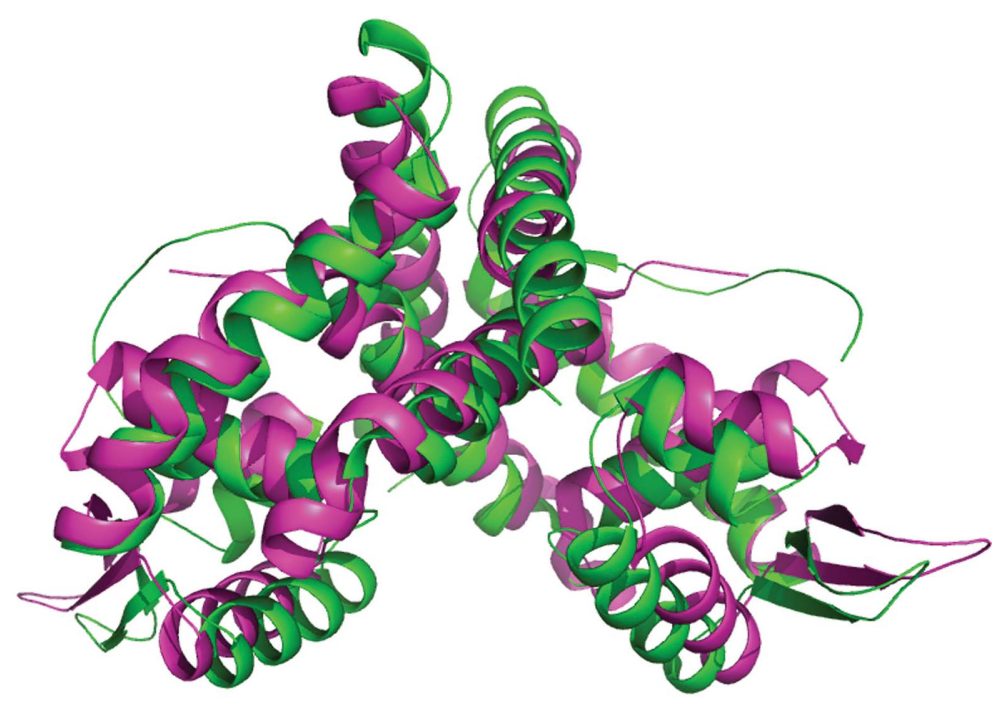

(b)

Figure 5

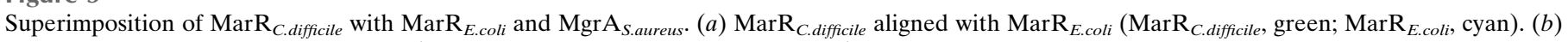
$\operatorname{MarR}_{\text {C.difficile }}$ aligned with $\mathrm{MgrA}_{\text {S.aureus }}\left(\mathrm{MarR}_{\text {C.difficile, }}\right.$, green; $\mathrm{MgrA}_{\text {S.aureus, }}$, purple). 


\section{Conclusion}

Although the MarR protein has been well studied in many species, the MarR protein from $C$. difficile remains unknown. The relationship between MarR and antibiotic resistance in C. difficile needs to be investigated. The crystal structure reported in this paper reveals MarR $\mathrm{R}_{\text {.difficile }}$ to be a crystallographic dimer. It shows structural similarity to other MarR family proteins. Furthermore, the structure of MarR in C. difficile suggests a putative DNA-binding site, revealing that the MarR protein in $C$. difficile might be also a transcription factor that can bind DNA. Based on the structural analysis of $\mathrm{MarR}_{\text {C.difficile, }}$, we found that the two cysteine residues could not be oxidized easily as they are located in the hydrophobic core. Therefore, MarR from $C$. difficile may not be an oxidation sensor. The solved crystal structure of $\operatorname{MarR}_{\text {C.difficile }}$ will be the first step in further functional studies.

\section{Acknowledgements}

We thank the staff of the BL17B/BL18U1/BL19U1/BL19U2/ BL01B beamlines of the National Center for Protein Sciences Shanghai (NCPSS) at Shanghai Synchrotron Radiation Facility for assistance during data collection. The authors also thank Shanghai Synchrotron Radiation Facility (SSRF) beamline BL17U for X-ray beam time.

\section{References}

Alekshun, M. N. \& Levy, S. B. (1997). Antimicrob. Agents Chemother. 41, 2067-2075.

Alekshun, M. N. \& Levy, S. B. (1999). Trends Microbiol. 7, 410-413.
Alekshun, M. N., Levy, S. B., Mealy, T. R., Seaton, B. A. \& Head, J. F. (2001). Nature Struct. Biol. 8, 710-714.

Brooun, A., Tomashek, J. J. \& Lewis, K. (1999). J. Bacteriol. 181, 5131-5133.

Chen, P. R., Bae, T., Williams, W. A., Duguid, E. M., Rice, P. A., Schneewind, O. \& He, C. (2006). Nature Chem. Biol. 2, 591-595.

Cohen, S. P., Levy, S. B., Foulds, J. \& Rosner, J. L. (1993). J. Bacteriol. 175, 7856-7862.

Gajiwala, K. S. \& Burley, S. K. (2000). Curr. Opin. Struct. Biol. 10, 110-116.

George, A. M. \& Levy, S. B. (1983). J. Bacteriol. 155, 541-548.

Hao, Z., Lou, H., Zhu, R., Zhu, J., Zhang, D., Zhao, B. S., Zeng, S., Chen, X., Chan, J., He, C. \& Chen, P. R. (2014). Nature Chem. Biol. 10, 21-28.

Heinlen, L. \& Ballard, J. D. (2010). Am. J. Med. Sci. 340, 247-252.

Hunt, J. J. \& Ballard, J. D. (2013). Microbiol. Mol. Biol. Rev. 77, 567-581.

Ingavale, S., van Wamel, W., Luong, T. T., Lee, C. Y. \& Cheung, A. L. (2005). Infect. Immun. 73, 1423-1431.

Lee, J.-W. \& Helmann, J. D. (2006). Nature (London), 440, 363-367.

Martin, R. G., Jair, K. W., Wolf, R. E. Jr \& Rosner, J. L. (1996). J. Bacteriol. 178, 2216-2223.

Martin, R. G., Nyantakyi, P. S. \& Rosner, J. L. (1995). J. Bacteriol. 177, 4176-4178.

Martin, R. G. \& Rosner, J. L. (1995). Proc. Natl Acad. Sci. USA, 92 , 5456-5460.

Murshudov, G. N., Skubák, P., Lebedev, A. A., Pannu, N. S., Steiner, R. A., Nicholls, R. A., Winn, M. D., Long, F. \& Vagin, A. A. (2011). Acta Cryst. D67, 355-367.

Otwinowski, Z. \& Minor, W. (1997). Methods Enzymol. 276, 307-326.

Perera, I. C. \& Grove, A. (2010). J. Mol. Cell Biol. 2, 243-254.

Potterton, E., Briggs, P., Turkenburg, M. \& Dodson, E. (2003). Acta Cryst. D59, 1131-1137.

Winn, M. D. et al. (2011). Acta Cryst. D67, 235-242.

Zhu, R., Hao, Z., Lou, H., Song, Y., Zhao, J., Chen, Y., Zhu, J. \& Chen, P. R. (2017). J. Biol. Inorg. Chem., https://doi.org/10.1007/s00775017-1442-7. 